\title{
Identification of Some Research Gaps in Green Human Resource Management
}

\author{
Hewapathirana, R.A. ${ }^{1}$, Opatha, H.H.D.N.P. ${ }^{2} \&$ Prasadini Gamage ${ }^{3}$ \\ ${ }^{1}$ DBA Researcher, University of Kelaniya, Sri Lanka \\ ${ }^{2}$ Senior Professor and Chair of HRM, Department of HRM, University of Sri Jayewardenepura, Sri Lanka \\ ${ }^{3}$ Professor in HRM, Department of HRM, University of Kelaniya, Sri Lanka \\ Correspondence: Hewapathirana, R. Athula, DBA Researcher, University of Kelaniya, Sri Lanka. E-mail: \\ rahewap-dba18014@kln.ac.lk
}

Received: August 20, 2020

Accepted: November 17, $2020 \quad$ Online Published: November 30, 2020

doi:10.5539/ibr.v13n12p63

URL: https://doi.org/10.5539/ibr.v13n12p63

\begin{abstract}
Green Human Resource Management (GHRM) is increasingly considered as a critical branch of Human Resource Management (HRM) and it is still an emerging field of research that is interesting and highly instrumental in creating and enhancing natural environmental sustainability. This research paper is a systematic attempt to find out some research gaps in GHRM in order to carry out future empirical studies through the adoption of desk research strategy. An extensive literature review was done and it resulted in identifying nine research gaps in GHRM. Among the nine research gaps, two gaps are empirical, six gaps are both theoretical and empirical, and one gap is methodological. Future research studies could be designed and carried out in order to fill these identified research gaps.
\end{abstract}

Keywords: desk research, human resource management, green human resource management, research gaps

\section{Introduction}

We live in a world which is experiencing increased globalization. In the present societies, environmental problems have been a serious concern with the acceleration of globalization (Aykan, 2017). In every developing nation there are continuous organizational endeavours to increase productivity to achieve its developmental goals. In every developed nation the same is happening. It is evident that general people and relevant organizations never stop their productivity improvements, increasing profits and profitability, and consumerism. Consequently, our natural environment is now in danger and the rapid increase in industrialization poses a serious threat to the nature and therefore, air and water pollution are the main problems in the natural environment (Dhawan, 2019). Hence, environmental issues such as pollution of the environment, global warming, sudden climate change, and energy crisis are very serious concerns of all over the world, and now dealing with these issues appropriately becomes one of the major responsibilities of all human beings throughout the world. In the $21^{\text {st }}$ century "sustainability" has become a critical issue for the world and for business (Das \& Singh, 2016, p.227). The most popular sustainability related paradigm is the Triple Bottom Line the three Ps of which stand for people, planet, and profits.

Opatha (2016) emphasized that "to have a balance among people, planet, and profits" (p.3) becomes imperative for any manager of any firm in order to ensure to experience a future that is sustainable. Also, he stressed that the firm is required to create, maintain, and improve the ability to excel in its environmental performance as well as its societal and ethical performance. Environmental performance is for the planet and societal and ethical performance is for people. Consequently, there is a highly felt need for HRM to be instrumental in transforming the firm to become a sustainable organization. The aspect or branch of HRM that is relevant in this regard is Green HRM. GHRM has green-oriented HRM functions which are executed to make normal employees green, and then they, who became green give, hopefully, their contributions in the way that is maximum to the environmental performance of the organization and subsequently environment sustainability (Opatha, 2019).

Renwick et al. (2008) stated that in managing human resources there are gaps which "exist in the HRM literature on the HR aspects of environmental management"(p.2). Opatha (2013) observed many gaps to be filled in respect of Green HRM necessitating theoretical and empirical studies to be carried out for the purpose of 
enhancing the body of knowledge of Green HRM (p.21). By the year 2013 there had been some developments with regard to research on Green HRM outside Sri Lanka (Opatha, 2013), and in and after 2013 several original research studies were done in Sri Lanka by Opatha (2013), Opatha and Arulrajah (2014), Arulrajah, Opatha and Nawaratne (2015), Arulrajah, Opatha and Nawaratne (2016), and Arulrajah and Opatha (2016). Indeed there is an increasing trend of researching GHRM and fortunately as a result of this trend, at present a considerable amount of literature of GHRM exists. Owing to the critical utility of GHRM for ensuring enriched sustainability and indeed our personal interest in GHRM it was intended to write this research paper with the main objective of discovering some research gaps in the literature of GHRM. Hopefully discovering some research gaps motivates future researchers including ourselves too to carry out basic research studies so that the existing body of knowledge of Green HRM gets expanded significantly.

\section{Objectives of Paper}

Specifically this paper attempts to achieve the following four objectives:

1. To present a brief introduction to Green HRM and identify related concepts.

2. To explore and specify the key studies on Green HRM.

3. To present certain research gaps in Green HRM.

4. To discuss future implications.

\section{Method}

The desk research strategy was adopted as it was appropriate in order to achieve the objectives of this study. A few key pioneering original studies were utilized for achieving the first objective while an extensive literature survey was carried out to achieve the second and the third objectives. The literature survey was based on the articles which were found from databases such as Emerald, JSTOR, Scopus, EBSCO Host, Oxford University Press, Sage, Research Gate, and Wiley Online Library. Books published under the subjects of 'Greening People' and 'Sustainable Human Resource Management' were utilized. As the literature of GHRM is contemporary and recently emerged, materials published from the year 2000 to 2020 were used.

\section{Literature Review}

According to the research papers (Opatha, 2013; Opatha and Arulrajah, 2014) the meaning of the term 'Green' or 'Greening' has four aspects and accordingly (1) the natural environment is to be preserved, (2) the natural environment is to be conserved, (3) the pollution of the natural environment is to be avoided or minimized, and (4) gardens and looking-like natural places are to be created (p.13, p.102). "The dictionary definitions (the Oxford Paperback Dictionary, 1979; Collins Birmingham University International Language Database English Language Dictionary, 1987: the New Oxford Thesaurus of English, 2000) with regard to the term 'Green' include several ones and two relevant definitions are: (1) a human quality of being environmentally friendly, and (2) a human being who is an environmentalist" inter alia (Opatha \& Hewapathirana, 2019, p.3). A person who needs to be a green person is required to play "four roles, i.e. preservationist, conservationist, non-polluter, and maker; and this person is identified as nature-lover or eco-activist" (Opatha, 2013, p.13; Opatha \& Arulrajah, 2014, p.102; Opatha, 2019, p.46). We expect that every employee needs to be seriously an environmentalist or eco-activist in order to achieve environmental sustainability.

"The integration of Corporate Environmental Management into HRM is GHRM" according to Renwick, Redman, and Maguire (2012, p.1). This definition suggests that GHRM derives from the existence of Corporate Environment Management (CEM). Wehrmeyer (1996) defines "CEM as the coordinated and organized approach to issues relating to the natural environment, from a business perspective with the aim of reducing those impacts deemed harmful to the natural environment". Further, he adds that CEM is about identifying, documenting, and eliminating environmental effects which are harmful to the nature. Environmental management deals with the work of minimizing and avoiding the harmful effects of business work in the organization to the natural environment, and it includes waste and materials reduction, energy efficiency, emissions control, etc. When environmental management goes in line with HRM which is managing human resources efficiently and effectively in an organization so that they become closely linked, the creation of GHRM occurs. The definition of GHRM given by Jabbour, Santos, and Nagano (2010) is important in this regard and it is "the greening of functional dimensions of HRM such as job description and analysis, recruitment, selection, performance appraisal, rewards, and training"(p.1057). It was observed that they utilized functional perspective to defining GHRM and when incorporating HRM functions such as analyzing jobs, recruiting, selecting, training, appraising employee job performance, managing wages and salaries, managing incentives, and managing welfare facilities with greening GHRM exists (Opatha \& Hewapathirana, 2019). According to Opatha (2013) a 
special system at the organizational level needs to be developed, implemented and maintained continuously in order to make normal "employees of an organization green, and the relevant set of activities involved in the development, implementation, and on-going maintenance of " (p.15), that special system is GHRM. This special system can include policies, procedures, and practices which focus on transforming general employees of the organization into eco-activists who will engage actively in performing various green tasks which are beneficial for the employee, society, natural environment, and the business. Under GHRM the needs of ecological sustainability become the concern which necessitates rethinking and performing HRM in an environment-friendly way (Arulrajah \& Opatha, 2016). This rethinking and performing of the work of managing employees in the organization create green orientation of all human resource functions or practices at all levels of the organization. We consider GHRM as Green Orientation of HRM (GOHRM) and it is nominally defined as the extent to which HRM functions in an organization have been made green.

A related concept is a pro-environmental behaviour. According to Ones and Dilchert "(2009, as in Mesmer-Magnus, Viswesvaran, and Wiernik, 2012) pro-environmental behaviour is an individual's behaviour that contributes to environmental sustainability, and it is volitional, intentional, and entirely under the control of that individual" (p.93). Further, the researchers observed that the research literature on pro-environmental behaviours has tended to focus on behaviours in non-work settings. However, Mesmer-Magnus et al. (2012) mentioned that behaviours such as reducing use, avoiding waste, recycling, and preventing pollution can be performed at work or in personal lives, but the latter affords a degree of individual control over behaviour that may not be possible in organizational settings. Opatha (2019) utilized the term 'green personal behaviour' to pro-environmental behaviour as an alternative term. He has defined it as "the extent to which the employee takes positive actions in respect of greening at personal life" (p.58).

Another related concept is individual environmental commitment. This is one specific type of green attitudes (Opatha, 2019). Defining of this concept by Mesmer-Magnus et al. (2012) is worthy of mentioning here and accordingly it is about the extent of the dedication of an individual to environmental sustainability and his or her degree of willingness of engaging behaviours which are called pro-environmental behaviours (p.94). According to them, specific behaviours which are in favour of sustaining the natural environment come under pro-environmental behaviours. When an individual limits consumption of energy, avoids waste as much as possible, recycles used things, and activates toward protecting the nature, he or she engages in environmental behaviours which are nature-friendly (p.89).

Also, they write (2012, p.160): “A distinguishing feature of these behaviors is that they are (1) intentional and (2) freely selected (that is, not under organizational control)." Their writing in addition to the above aspects focuses on attitudes of individuals in respect of the natural environment and a pivotal role is played by such attitudes in explaining the processes which come under nature-friendly behaviours. The defining of the environmental attitude of an individual by scholars namely Eagly and Chaiken (1993) includes that a person tends psychologically to evaluate a particular entity of the nature or the nature as a whole with a certain amount of favour or disfavor. A positive attitude includes favorability with which the person views the natural environment generally or specific ecological matters particularly. Two scholars namely Kollmuss and Agyeman (2002) emphasize a recognition given by early models of pro-environmental behaviours and that is: a person's knowledge about the natural environment is not adequate to influence him or her to engage in actions which lead to protecting the natural environment and hereby his or her positive attitude about the natural environment is needed. The environmental knowledge has to be utilized through the positive environmental attitude to affect behaviour which is nature-friendly. According to what has been observed and written by the above scholars, both environmental knowledge and environmental attitude are necessary to produce an effect on environmental behaviour. One's environmental behaviour includes actions in favour of the natural environment.

Having added to the existing body of knowledge of GHRM Opatha and Arulrajah (2014) discuss four types of green human resource requirements and they include green competencies, green attitude, green behaviour, and green results (p.105). These four requirements can be identified as four concepts related to GHRM. Further, they conceptualize that green behaviour is a broad concept and it includes "three dimensions, i.e. green organizational citizenship behaviour, green interpersonal citizenship behaviour, and green official behavior" (p.105), which can also be identified as another three GHRM-related concepts. Green results consist of two dimensions such as green innovations and green outcomes. The meanings of those concepts are proposed by Opatha and Arulrajah (2014) are presented in Table 1. 
Table 1. Meanings of the Concepts of GHRM

\begin{tabular}{|c|c|}
\hline Concept & Definition \\
\hline Green Competencies & $\begin{array}{l}\text { A person who is required to be a green person should possess knowledge and skills about } \\
\text { preserving and conserving the natural environment, avoiding or reducing its pollution, and } \\
\text { generating gardens and looking-like natural places. }\end{array}$ \\
\hline Green Attitude & $\begin{array}{l}\text { A person who is supposed to be a green one should believe in greening, feel it positively } \\
\text { and interestingly, and tend to behave positively and seriously towards it. The person's } \\
\text { attitude needs to be complete cognitively, affectively, and behaviourally as well. }\end{array}$ \\
\hline Green Behaviour & $\begin{array}{l}\text { A person who is supposed to be green should engage in various actions the totality of which } \\
\text { falls under three general labels i.e. green organizational citizenship behaviour, green } \\
\text { interpersonal citizenship behaviour, and green official behaviour. }\end{array}$ \\
\hline $\begin{array}{l}\text { Green Organizational } \\
\text { Citizenship Behaviour }\end{array}$ & $\begin{array}{l}\text { A person who is required to be green should involve in executing certain actions or } \\
\text { activities which are in support of the attempt taken by the organization to achieve the goal } \\
\text { of greening. Such activities performed by the employee are not the duties which have been } \\
\text { specified in the job description given to him or her by the organization. }\end{array}$ \\
\hline $\begin{array}{l}\text { Green Interpersonal } \\
\text { Citizenship Behaviour }\end{array}$ & $\begin{array}{l}\text { A person who is supposed to be green should involve in doing certain actions or activities } \\
\text { which are in support of making peers and others green. The actions done by the employee to } \\
\text { assist other employees to contribute to greening are not official tasks or duties to be } \\
\text { performed as per the job description. }\end{array}$ \\
\hline Green Official Behaviour & $\begin{array}{l}\text { A person who is required to be a green employee must perform certain activities or do } \\
\text { certain actions on greening specified officially by the organization. The actions done by the } \\
\text { employee are not volitional ones, but duties which have been specified in the job description } \\
\text { given to him or her by the respective organizational authority. }\end{array}$ \\
\hline Green Innovations & $\begin{array}{l}\text { A person who became a green employee should be able to make things which are useful for } \\
\text { the realization of greening by using new ideas. Such innovations are to be schemes, } \\
\text { solutions, procedures, measures, etc., for reducing waste, minimizing damages to nature, } \\
\text { and expanding nature. }\end{array}$ \\
\hline Green Outcomes & $\begin{array}{l}\text { A person who became a successful green employee should be able to make certain outputs } \\
\text { or results as evidence of the realization of greening to a significant extent. Such green } \\
\text { outcomes can include the extent to which the employee worked with the natural light (in } \\
\text { terms of hours), the extent to which the employee used electricity bulbs (in terms of } \\
\text { number), the extent to which the employee reduced electricity consumption (in terms of } \\
\text { expenditure), the extent to which the employee reduced wastage (in terms of units or } \\
\text { expenditure), etc. }\end{array}$ \\
\hline Employee Green Inputs & $\begin{array}{l}\text { A person who is supposed to be green should possess two types of resources or assets and } \\
\text { they include his or her competencies and attitude with regard to greening. }\end{array}$ \\
\hline $\begin{array}{l}\text { Employee Green Performance } \\
\text { of Job }\end{array}$ & $\begin{array}{l}\text { A person who is a green employee should contribute to fulfilling the green aspects of his or } \\
\text { her job and they include behaviour and results on greening. }\end{array}$ \\
\hline
\end{tabular}

Source: Based on Material by Opatha and Arulrajah (2014, pp.105,106,107)

When certain human resources practices are practiced in a way that is compatible and go in line the results of such practices become most effective. This is indeed an important research finding (MacDuffie, 1995). Based on this research finding Opatha (2019) introduced a concept called Green Human Resource Bundle which refers to a set of green oriented or greening embedded human resource functions that are practiced in an internally consistent way and each function supports the others. "A Green HR Bundle has a group of green HRM practices which work together to create a consistent impact on greening people at work" (Opatha, 2019, p.52). Owing to a green HRM bundle it avoids situations where one HR function becomes green while other HR functions are not and therefore hindering or minimizing the degree of achievement of the generic goal or purpose of GHRM. The green HRM bundle attempts to do that each normal employee is transformed into a green employee who is identified especially as an eco-activist or a nature lover. A maximum contribution at the individual level on the "four roles, i.e., preservationist, conservationist, non-polluter, and maker" is expected from each employee in the organization under the purpose of GHRM (Opatha, 2013, p.15; Opatha \& Arulrajah, 2014, p.104).

\section{Key Studies on Green HRM}

Key studies on GHRM done by various scholars from 2004 to 2020 were explored and examined to know the aspects studied. These studies were international as well as local and summaries of such studies are presented in Table 2. 
Table 2. Key Studies on Green HRM

\begin{tabular}{|c|c|c|}
\hline Author & Year & Description \\
\hline Purba Rao & 2004 & $\begin{array}{l}\text {-This is a research paper studying the relevance of the "greening of production" in } \\
\text { the South-East Asian context. The study investigates the various initiatives taken by } \\
\text { the companies in the region and finally identifies the factors that are critical in the } \\
\text { process of greening production in this region. }\end{array}$ \\
\hline $\begin{array}{l}\text { Kamal M. } \\
\text { and Vinnie } \mathrm{J} .\end{array}$ & 2007 & $\begin{array}{l}\text {-This study attempts to search the factors which affect the attitude and behaviour of } \\
\text { the consumer for green practices in the Indian lodging industry and it also researches } \\
\text { the consumers' intentions to pay for green practices. }\end{array}$ \\
\hline $\begin{array}{l}\text { Renwick D.W.S., } \\
\text { Redman Tom } \\
\text { and } \\
\text { Maguire S. }\end{array}$ & 2008 & $\begin{array}{l}\text {-These three researchers in the study take a new and integrated view of the literature } \\
\text { in respect of Green HRM. The study does classify the literature on the basis of } \\
\text { entry-to-exit processes in HRM (from recruitment to exit). Further, it does reveal } \\
\text { that HR processes play in translating Green HR policy into practice. The paper has a } \\
\text { contribution of drawing together the extant literature in this area, mapping the terrain } \\
\text { in this field, and proposes a new process model and research agenda in Green HRM. }\end{array}$ \\
\hline Lee Ki-Hoon & 2009 & $\begin{array}{l}\text { - The relevant study was done in enterprises which are small and medium-sized and } \\
\text { it contributed by exploring and investigating the process of green management } \\
\text { adopted by those organizations. }\end{array}$ \\
\hline $\begin{array}{l}\text { Jabbour C.J.C, Santos, } \\
\text { F.C.A. } \\
\text { and } \\
\text { Nagano, M.S. }\end{array}$ & 2010 & $\begin{array}{l}\text {-These researchers have done a comprehensive study in order to analyze the } \\
\text { contribution of HRM throughout the evolutionary stages of environmental } \\
\text { management in Brazilian companies. The research paper has a contribution in terms } \\
\text { of a theoretical framework of environmental management and its evolution and the } \\
\text { 'greening' of the HRM functional and competitive dimensions. }\end{array}$ \\
\hline Smith E.E. and Perks S. & 2010 & $\begin{array}{l}\text {-This study has an in-depth literature review and empirical evidence on managerial } \\
\text { perception with regard to green implementation under the business functions. }\end{array}$ \\
\hline $\begin{array}{l}\text { Jackson Susan E., } \\
\text { Renwick D.W. S., } \\
\text { Jabbour C. J. C. and } \\
\text { Muller-Camen M. }\end{array}$ & 2011 & $\begin{array}{l}\text {-These researchers have done a study on Green HRM. It contributes to the existing } \\
\text { body of literature by expanding the field of HRM in the context of environmental } \\
\text { management. It discusses the HRM's role in the pursuit of environmentally } \\
\text { sustainable business and concludes by describing opportunities for future research at } \\
\text { the intersection of environmental management and strategic HRM. }\end{array}$ \\
\hline Jabbour C.J.C. & 2011 & $\begin{array}{l}\text {-This research paper is on a study done in } 94 \text { Brazilian companies that have ISO } \\
14001 \text { certification. It analyses the degree of the greening of HRM practices, } \\
\text { organizational culture, learning, and teamwork. }\end{array}$ \\
\hline Suhaimi Sudin & 2011 & $\begin{array}{l}\text { - This paper is based on a study that attempts to explore the relevant constructs of } \\
\text { green HRM. In addition, the study proposes a model of strategic green HRM } \\
\text { deriving from the literature about HRM phases of environmental management. }\end{array}$ \\
\hline $\begin{array}{l}\text { Renwick D.W.S, } \\
\text { Redman T. and } \\
\text { Maguire S. }\end{array}$ & 2012 & $\begin{array}{l}\text {-This research is based on a study that presents the extant literature of GHRM and } \\
\text { attempts to map the terrain of the field. Also, it identifies some gaps in the existing } \\
\text { literature and suggests some agendas for future research studies. }\end{array}$ \\
\hline Dutta S. & 2012 & $\begin{array}{l}\text {-This researcher has done a study with a focus on GHRM as a strategic initiative by } \\
\text { the corporate for the purpose of promoting sustainable business practices. }\end{array}$ \\
\hline Eryuruk S.H. & 2012 & $\begin{array}{l}\text {-The researcher attempts to analyze vital points and parameters way of taking the } \\
\text { textile and clothing industry towards greening the product lifecycle from raw } \\
\text { material through design, production, and logistics ending up from the disposal } \\
\text { process. }\end{array}$ \\
\hline Opatha H.H.D.N.P. & 2013 & $\begin{array}{l}\text {-The researcher has done a conceptual paper that gives some original theoretical } \\
\text { formulations with regard to GHRM after understanding the meaning of green or } \\
\text { greening. }\end{array}$ \\
\hline $\begin{array}{l}\text { Bissing-Olson M. J., } \\
\text { IyerA., Fielding K. S., } \\
\text { and Zacher H. }\end{array}$ & 2013 & $\begin{array}{l}\text { - This study was dedicated to understanding the factors of employee green behavior } \\
\text { having investigated the relationship between employees' pro-environmental attitude, } \\
\text { daily task-related pro-environmental behavior (the level to which employees } \\
\text { complete their work tasks in environmentally-friendly ways), daily proactive } \\
\text { pro-environmental behavior (the level at which employees show personal initiative } \\
\text { when acting in environmentally-friendly ways at work) and employees daily affect. }\end{array}$ \\
\hline $\begin{array}{l}\text { Opatha H.H.D.N.P. } \\
\text { and } \\
\text { Arulrajah A. A. }\end{array}$ & 2014 & $\begin{array}{l}\text {-The researchers through this research paper produced an expanded version of a } \\
\text { previous original theoretical work done by one author. This conceptual work } \\
\text { describes what greening means, explains reasons for greening and its importance, } \\
\text { presents four green human resource requirements, shows a possible way of making } \\
\text { HRM functions green, and finally presents the findings of some research done in the } \\
\text { field of GHRM. }\end{array}$ \\
\hline $\begin{array}{l}\text { Obaid T. F. and } \\
\text { Alias R. Bte. }\end{array}$ & 2015 & $\begin{array}{l}\text {-This is a study theoretical researching effect of HRM factors such as recruitment, } \\
\text { training and development, and learning under the concept of greening to the } \\
\text { performance of the firm. }\end{array}$ \\
\hline $\begin{array}{l}\text { Aggarwal S. } \\
\text { and } \\
\text { Sharma B. }\end{array}$ & 2015 & $\begin{array}{l}\text {-This paper attempts to comprehend the idea of Green and Green HRM, its } \\
\text { significance, focal points, and limitations for the respective organization that desires } \\
\text { to make due in this modern period with a perspective on sustainability and further, it }\end{array}$ \\
\hline
\end{tabular}




\begin{tabular}{|c|c|c|}
\hline & & $\begin{array}{l}\text { is trusted that this paper presents some utility for evolving interests within potential } \\
\text { students, academicians, and research scholars and gaining knowledge and } \\
\text { understand green HRM theoretically. }\end{array}$ \\
\hline $\begin{array}{l}\text { Bangwal D. } \\
\text { and } \\
\text { Tiwari P. }\end{array}$ & 2015 & $\begin{array}{l}\text {-This paper aims to study the GHRM, different Practices of Green Human Resource, } \\
\text { and clarifies the function of the green human resource process towards green and } \\
\text { afterward the paper recommends some social ramifications of practices of Green } \\
\text { human resources to bring organization towards green. }\end{array}$ \\
\hline $\begin{array}{l}\text { Nejati M. and } \\
\text { Ahmad N.H. }\end{array}$ & 2015 & $\begin{array}{l}\text {-This is a paper investigating the effectiveness of green human resource } \\
\text { management (GHRM) in the influential perception of job seekers in respect of the } \\
\text { glory of an organization and attractiveness, having the purpose of obtaining } \\
\text { applications from job seekers. By using a sample of } 162 \text { applicants in Malaysia, } \\
\text { particular research framework was tested through a model of partial least squares } \\
\text { structural equation (PLS SEM). }\end{array}$ \\
\hline $\begin{array}{l}\text { Mehta K. and } \\
\text { Chugan P.K. }\end{array}$ & 2015 & $\begin{array}{l}\text {-The researchers attempt to define the concept of GHRM, methodology practicing } \\
\text { by organizations headed to green HRM, its points of interest, particular practices, } \\
\text { and policies through this paper. Further, it explains present trends in respect to green } \\
\text { HRM practices in organizations according to the findings of a couple of studies, } \\
\text { some survey reports, and available information on web sites of the companies. That } \\
\text { additionally draws out the part of HRM work towards making a 'green' culture in } \\
\text { organizations. }\end{array}$ \\
\hline $\begin{array}{l}\text { Guerci M. and } \\
\text { Carollo L. }\end{array}$ & 2015 & $\begin{array}{l}\text {-The researchers attempt from this paper to take the still unexplored opportunity to } \\
\text { apply paradox theory to green HRM and search the HRM-related paradoxes } \\
\text { supposed by organizations to develop a sustainable environment. Data collection has } \\
\text { been carried out within six companies in Italy by using a methodology of case study, } \\
\text { semi-structured interviews, and analysis of the document. }\end{array}$ \\
\hline $\begin{array}{l}\text { Arulrajah A.A, } \\
\text { Opatha H.H.D.N.P. and } \\
\text { Nawaratne N.N.J. }\end{array}$ & 2015 & $\begin{array}{l}\text {-The researchers have done research work in terms of a systematic review of the } \\
\text { existent literature. The review attempts to explore, identify, and describe green } \\
\text { human resource management practices of organizations. }\end{array}$ \\
\hline $\begin{array}{l}\text { Jabbar M. H. and } \\
\text { Abid M. }\end{array}$ & 2015 & $\begin{array}{l}\text { This paper was dedicated to the study of GHRM practices while having a detailed } \\
\text { analysis of the same in respect of environmental performance in green organization } \\
\text { and findings of the same will be guided managers to improve the performance of the } \\
\text { organization along with achieving set goals. }\end{array}$ \\
\hline Ahmad S. & 2015 & $\begin{array}{l}\text {-This study mainly focuses on the different Green Human Resource practices } \\
\text { followed in the organization all over the world, and more it's describing the meaning } \\
\text { of GHRM in simplified terms. Further, this study adds literature to the existing } \\
\text { academic world by giving future direction in respect of some functions of GHRM. } \\
\text { The paper finally proposed some possibly productive HR initiatives to the } \\
\text { organization which concerns Green. }\end{array}$ \\
\hline $\begin{array}{l}\text { Renwick D.W.S., } \\
\text { Jabbour C.J.C., Muller } \\
\text {-Camen M., Redman T. } \\
\text { and Wilkinson A. }\end{array}$ & 2015 & $\begin{array}{l}\text {-This paper is in the contemporary writing on GHRM to logically outline the seven } \\
\text { articles that uncover the inserted idea of GHRM of practices of the work } \\
\text { environment. }\end{array}$ \\
\hline $\begin{array}{l}\text { Yusoff Y.M., Othman } \\
\text { N.Z., Fernando Y. and } \\
\text { Amran A. }\end{array}$ & 2015 & $\begin{array}{l}\text { - The researchers wrote this paper in an under-researched area in the field by } \\
\text { contributing theoretical and practical thoughts about the nature of Green Human } \\
\text { Resource Management (GHRM) in Malaysian multinational organizations. }\end{array}$ \\
\hline Dangmei J. & 2015 & $\begin{array}{l}\text { - This is a paper focused to observe the nature and implications in respects of } \\
\text { initiatives of Green HRM and practices of Green HRM which direct sustainability of } \\
\text { environment return advantage to the living ancestral individuals. An endeavor is } \\
\text { made to advance the significance of Green HRM and attempts to connect its } \\
\text { suggestions on saving the habitations of the ancestral populated zones. }\end{array}$ \\
\hline $\begin{array}{l}\text { Arulrajah A.A } \\
\text { and } \\
\text { Opatha H.H.D.N.P. }\end{array}$ & 2016 & $\begin{array}{l}\text { - These researchers produced a research paper which is of theoretical nature and it } \\
\text { presented a simplified underpinning for GHRM. The paper systematically attempts } \\
\text { to give analytical and theoretical frameworks for GHRM. Finally, a strong link } \\
\text { between both GHRM literature and theories of organizations is established. }\end{array}$ \\
\hline $\begin{array}{l}\text { Arulrajah A.A, } \\
\text { Opatha H. H. D. N. P. } \\
\text { and } \\
\text { Nawaratne N.N.J. }\end{array}$ & 2016 & $\begin{array}{l}\text { - The research paper is a systematic comprehensive conceptual paper that originally } \\
\text { presents a concept called "employee green performance of job". This conceptual } \\
\text { work defines the new concept, describes its dimensions, and finally identifies } \\
\text { elements with regard to each dimension. The identified three key dimensions and } \\
\text { eleven elements of the concept of employee green performance of job will have } \\
\text { utility for the purpose of developing a device to measure the construct. }\end{array}$ \\
\hline $\begin{array}{l}\text { Pallavi E.V.P.A.S. and } \\
\text { Bhanu M.V.V. }\end{array}$ & 2016 & $\begin{array}{l}\text { - This paper conversed on the Green HRM concept, sustainability in the corporate } \\
\text { environment, and way of executing functions of HR within Green culture. }\end{array}$ \\
\hline Pawar Avinash & 2016 & $\begin{array}{l}\text { - This article aims to realize the recommendations in respect of the requirement and } \\
\text { immensity of GHRM in sustainable Business. }\end{array}$ \\
\hline $\begin{array}{l}\text { Wayne O. and } \\
\text { Nuttaneeya A.T. }\end{array}$ & 2016 & $\begin{array}{l}\text { - This study has been indicated a relationship between firm performance and positive } \\
\text { acceptance of green management practices. Anyway, this exploration carried out } \\
\text { especially in the firm context which is small and has analyzed the effect of HR }\end{array}$ \\
\hline
\end{tabular}




\begin{tabular}{|c|c|c|}
\hline & & $\begin{array}{l}\text { management (HRM) practices on that affiliation. This paper contributes an empirical } \\
\text { assessment of the moderating effect of HRM on the relationship between firm } \\
\text { financial performance and proactive environmental management by analyzing data } \\
\text { collected from } 158 \text { small Australian machinery firms as a sample. }\end{array}$ \\
\hline Das S.C. and Singh R.K. & 2016 & $\begin{array}{l}\text { - This paper focuses on examining the relationship between organizational } \\
\text { sustainability and green HRM through the study on the international and national } \\
\text { levels. Further too, it outlines by what method green HRM and HR experts get } \\
\text { access to developing a body of knowledge to guide them on their sustainability } \\
\text { journey of the organization. }\end{array}$ \\
\hline $\begin{array}{l}\text { Gholami H., Rezaei } \\
\text { G., Mat Saman M. Z., } \\
\text { Sharif S. and Zakuan N. }\end{array}$ & 2016 & $\begin{array}{l}\text { - This paper aims to study by having a conversation concerning practices of GHRM, } \\
\text { which arise with the Ability-Motivation-Opportunity (AMO) hypothetical focal } \\
\text { point to drive sustainability. }\end{array}$ \\
\hline $\begin{array}{l}\text { Yong J.Y. } \\
\text { and } \\
\text { Yusliza M.Y. }\end{array}$ & 2016 & $\begin{array}{l}\text { - The motivation behind this paper is to analyze the impact of strategic human } \\
\text { resource (HR) proficiencies of HR experts on the acceptance of practices of green } \\
\text { human resource management (HRM). }\end{array}$ \\
\hline $\begin{array}{l}\text { Yusliza M.Y., } \\
\text { Othman N.Z. } \\
\text { and } \\
\text { Jabbour C.J.C. }\end{array}$ & 2017 & $\begin{array}{l}\text { - The main purpose of this study is to reason out basically how electronic human } \\
\text { resource management, green empowerment of employees, and the role of human } \\
\text { resource business partners may impact practices of green HRM by representation on } \\
\text { the resource-based view (RBV) theory. }\end{array}$ \\
\hline $\begin{array}{l}\text { Azmi F.R., Musa H., } \\
\text { Shahbodin F., } \\
\text { Hazmilah H. and } \\
\text { Fam S. }\end{array}$ & 2017 & $\begin{array}{l}\text { - The study mainly focuses on Employee Knowledge (EK), Employee Skill (ES), } \\
\text { and Employee Attitude (EA) towards the execution of Green Human Resource } \\
\text { Management (GHRM) and the reasonableness of this investigation, When the } \\
\text { employee skill are stressed that GHRM is foreseen to be very much implemented. }\end{array}$ \\
\hline $\begin{array}{l}\text { Toprak T. } \\
\text { and } \\
\text { Anis P. }\end{array}$ & 2017 & $\begin{array}{l}\text { - This paper mainly underlines impacts of environmental to textiles and way of } \\
\text { contribution done by cleaner production and maintainability in the textile industry } \\
\text { by opening a conversation on the open door for change in the processes of textile as } \\
\text { per the laws. }\end{array}$ \\
\hline $\begin{array}{l}\text { Bangwal D.,Tiwari P. } \\
\text { and } \\
\text { Chamola P. }\end{array}$ & 2017 & $\begin{array}{l}\text { - This article focused to analyze in what way green human resource management } \\
\text { contributes to the performance of nature through work-life of worker. According to a } \\
\text { detailed review of literature on GHRM and performance of the environment, a } \\
\text { conceptual model was established to research on direct and indirect effects of } \\
\text { GHRM on the performance of the environment have tested by using the } \\
\text { methodology of the model of the structural equation by using } 356 \text { leadership } \\
\text { employees survey data, collected from the certified companies of energy and } \\
\text { environmental design (LEED). }\end{array}$ \\
\hline $\begin{array}{l}\text { Ragas S.F.P, Tantay } \\
\text { F.M.A, Co Chua L.J. } \\
\text { and } \\
\text { Concha Sunio C.M. }\end{array}$ & 2017 & $\begin{array}{l}\text { - These researchers have done a study on employee job performance in few } \\
\text { industries and search the moderating role of the green lifestyle to the impact of } \\
\text { GHRM on the performance of the employees in particular industries and a potential } \\
\text { overflow of GHRM to employee lifestyle. }\end{array}$ \\
\hline $\begin{array}{l}\text { Dumont J., Jie Shen, and } \\
\text { Deng Xin }\end{array}$ & 2017 & $\begin{array}{l}\text { - This study focused on empirically testing the impact of GHRM on employee green } \\
\text { behavior at the workplace. }\end{array}$ \\
\hline $\begin{array}{l}\text { Kumar Kar A. } \\
\text { and } \\
\text { Praharaj L. }\end{array}$ & 2017 & $\begin{array}{l}\text { - The researchers have done a study by focusing mainly on several practices of } \\
\text { GHRM \& some limited initiatives. And too, a particular paper proposed a few } \\
\text { productive HR initiatives focusing on Green organizations. }\end{array}$ \\
\hline Pavitra M. & 2017 & $\begin{array}{l}\text { - The research area of this study, is the challenges and position of practices of } \\
\text { GHRM in India. Also, they propose a conceptual framework in order to fill the gaps } \\
\text { which have been identified to make a sustainable organization. }\end{array}$ \\
\hline $\begin{array}{l}\text { Javed F. and } \\
\text { Cheema S. }\end{array}$ & 2017 & $\begin{array}{l}\text { - This paper was on identifying the progress of agriculture through different ways of } \\
\text { practices of GHRM which helping to the progress of the same now and future. And } \\
\text { it has been found from this paper that in Pakistan, GHRM has very little understood. }\end{array}$ \\
\hline Coskun A. & 2017 & $\begin{array}{l}\text { - The particular study mainly focuses on green attitudes with firm instruments and, } \\
\text { in what way did measure the same and discussed changes of insights of green } \\
\text { attitude highlighting the significance of novel methods for attitude measurement. }\end{array}$ \\
\hline $\begin{array}{l}\text { Banerjee S. } \\
\text { and } \\
\text { Dutta A.B. }\end{array}$ & 2017 & $\begin{array}{l}\text { - The researchers had this study while focusing on concisely understanding green } \\
\text { human resource management, practices relating to GHRM, other possible initiatives } \\
\text { for structuring GHRM further, and finally rewards of green human resource } \\
\text { management. }\end{array}$ \\
\hline Aykan E. & 2017 & $\begin{array}{l}\text { - This article forces on scholarly work of GHRM and practices that are appraised } \\
\text { while highlighting important matters and recommendations done for future } \\
\text { researchers who wish to research this subject. }\end{array}$ \\
\hline $\begin{array}{l}\text { Ren S. ,Tang G. } \\
\text { and } \\
\text { Jackson S.E. }\end{array}$ & 2017 & $\begin{array}{l}\text { - This article looking for a clear understanding of research openings and advanced } \\
\text { development of theoretical and empirical, gauges the developing GHRM academic } \\
\text { field having a narrative review. And this paper review highlights a vital need to } \\
\text { develop a measurement of GHRM and conceptualization while improving a } \\
\text { combined model of the consequences, antecedents, and contingencies concerning } \\
\text { GHRM. }\end{array}$ \\
\hline Siyambalapitiya J., & 2018 & - This paper endeavor to distinguish practices of GHRM through reviewing the \\
\hline
\end{tabular}




\begin{tabular}{|c|c|c|}
\hline $\begin{array}{l}\text { Xu Zhang } \\
\text { and } \\
\text { Xiaobing L. }\end{array}$ & & $\begin{array}{l}\text { literature of GHRM from } 1996 \text { to } 2017 \text { while conducting face to face discussion } \\
\text { with HR experts to decide their perspectives on such concepts. Further, a novel } \\
\text { model was proposed to research the relationship between tasks of GHRM and } \\
\text { measurements of environmental management which help to improve the } \\
\text { performance of the environment. }\end{array}$ \\
\hline $\begin{array}{l}\text { Bohlmann C., Jeroen } \\
\text { V.D.B. } \\
\text { and } \\
\text { Zacher H. }\end{array}$ & In press & $\begin{array}{l}\text { - This paper addresses the significance of the green behaviour of an employee to the } \\
\text { ratings of overall job performance which include task performance, counter } \\
\text { productive work behavior, and organizational citizenship behaviour. This study was } \\
\text { carried out through the design of experimental policy capturing. }\end{array}$ \\
\hline $\begin{array}{l}\text { Saeed, B.B., Afsar, B., } \\
\text { Hafeez, S., Khan, I., } \\
\text { Tahir, M. } \\
\text { and } \\
\text { Muhammad A. A. }\end{array}$ & 2018 & $\begin{array}{l}\text { - The researchers have done this study by concerning the impact of practices of } \\
\text { green HRM (green selection and recruitment, green appraisal and performance } \\
\text { management, green reward and compensation, green training and development, and } \\
\text { green empowerment) on employee pro-environmental behavior while testing the } \\
\text { mediating and moderating effect of pro-environmental psychological capital and } \\
\text { environmental knowledge on green HRM practices, respectively and the relationship } \\
\text { of pro-environmental behavior. }\end{array}$ \\
\hline Chaudhary R. & 2018 & $\begin{array}{l}\text { - This paper focus to study the impact of perceived green human resource } \\
\text { management (GHRM) on job pursuit intention (JPI) of employees who are in a } \\
\text { status of potential and exertion was made to open up the highlighted psychological } \\
\text { mechanisms while fixing a limitation for the above relationship by introducing a } \\
\text { mediator as organizational prestige (OP) and environmental orientation (EO) and } \\
\text { gender as moderators. }\end{array}$ \\
\hline Yusuph M.L. & 2018 & $\begin{array}{l}\text { - This paper mainly aims at important approaches of sustaining the environment, } \\
\text { having make aware initiatives to the HR managers and employees in respect of the } \\
\text { importance of Green HRM, the green movement and just only conserve resources of } \\
\text { natural very carefully to meet requirement of the organization and reserve nature for } \\
\text { the development of future sustainability and preserve total safety and wellbeing of } \\
\text { employees and customers. }\end{array}$ \\
\hline $\begin{array}{l}\text { Halawi A. } \\
\text { and } \\
\text { Zaraket W. }\end{array}$ & 2018 & $\begin{array}{l}\text {-This research paper exploration by arguing that Lebanese privately owned } \\
\text { businesses can secure an edge what time accepting Green responsibility excessively } \\
\text { by the management of human resources, specially within the existence of } \\
\text { characteristic of huge rivalry in numerous industries and attempted to investigate the } \\
\text { position of Lebanese organizations in regards to Green HRM on work behaviour of } \\
\text { the employees through using a model of two Lebanese organizations which } \\
\text { represent two different industries of a university and a bank. }\end{array}$ \\
\hline $\begin{array}{l}\text { Bombiak E. } \\
\text { and } \\
\text { Marciniuk-Kluska A. }\end{array}$ & 2018 & $\begin{array}{l}\text { - This paper aims to study to identify the HR practices on pro-environmental } \\
\text { compelled by young Polish enterprises and to line-up the same as per their } \\
\text { consequence on the sustainable development of the organization. }\end{array}$ \\
\hline $\begin{array}{l}\text { Zaid A. A., Bon A.T. } \\
\text { and } \\
\text { Jaaron A.A.M. }\end{array}$ & 2018 & $\begin{array}{l}\text { - This research paper mainly focuses on the practices of GHRM as together of a } \\
\text { bundle rather than the practices of the individual. It has been given many advantages } \\
\text { to the industries and the literature with respect to the relationship between practices } \\
\text { of the GHRM bundle and four components which was inspected under organization } \\
\text { performance. What's more, research was proposed a theoretical model to explain the } \\
\text { association between practices of the GHRM bundle and the performance of the } \\
\text { organization. }\end{array}$ \\
\hline $\begin{array}{l}\text { Yua W., Chavezb R., } \\
\text { Fengc M., Wongd C. Y. } \\
\text { and Fynese B. }\end{array}$ & 2019 & $\begin{array}{l}\text { - The researchers have done the study by researching the significance of GHRM } \\
\text { associate with the environmental collaboration among suppliers and customers } \\
\text { which impact the moderating role of internal green supply chain management } \\
\text { (GSCM). The particular survey was done through } 126 \text { manufactures who engage in } \\
\text { the automobile industries in china by using regression analysis which moderated } \\
\text { through a conceptual framework, guided from the contingency theory and ability- } \\
\text { motivation-opportunity theory. }\end{array}$ \\
\hline Shah M. & 2019 & $\begin{array}{l}\text {-This study attempts to develop a measurement of scale in respect of green human } \\
\text { resource management which is be effective. }\end{array}$ \\
\hline $\begin{array}{l}\text { Shahriari B. and } \\
\text { Hassanpoor A. }\end{array}$ & 2019 & $\begin{array}{l}\text { - The researchers have done a systematic review of studies done during the previous } \\
\text { ten years in respect of Green HRM in the west and east. }\end{array}$ \\
\hline Dhawan S. & 2019 & $\begin{array}{l}\text { - This paper attempted to study how Green HR practices recognize by the Indian } \\
\text { Companies and their advantages. What's more, moreover it attempted to research the } \\
\text { future of GHRM in the country of India. }\end{array}$ \\
\hline $\begin{array}{l}\text { Arqawi S., Zaid A.A., } \\
\text { Ayham A.M., Al hila A. } \\
\text { J., Al Shobaki M.J. and } \\
\text { Abu-Naser S.S. }\end{array}$ & 2019 & $\begin{array}{l}\text { - The researchers carried out their study by researching the opinion and level of } \\
\text { recognition of practices of GHRM in the Palestinian manufacturing organizations } \\
\text { and as findings, the paper was concluded by highlighting those Palestinian } \\
\text { organizations have been practiced GHRM practices in some extended level. }\end{array}$ \\
\hline $\begin{array}{l}\text { Yong J.Y., } \\
\text { Yusliza M.Y. and } \\
\text { Fawehinmi O. O. }\end{array}$ & 2019 & $\begin{array}{l}\text { - This paper surveyed on Green HRM literature of different degrees, approaches, and } \\
\text { settings, to identify the same which focus on different areas. Finally, it has proposed } \\
\text { future research areas. }\end{array}$ \\
\hline Pham N.T., & 2019 & - This is a paper, testing a conceptual framework that is novel, extended through the \\
\hline
\end{tabular}




\begin{tabular}{|l|l|l|}
\hline $\begin{array}{l}\text { TuckovaZuzana } \\
\text { and } \\
\text { Phan Q.P.T. }\end{array}$ & $\begin{array}{l}\text { theories of Ability-Motivation-Opportunity and Social exchange within a context of } \\
\text { green. The particular conceptual framework was explored the indirect and } \\
\text { collaborative effects of training, reward, and organizational culture under practices } \\
\text { of Green HRM on employee commitment to the environment. }\end{array}$ \\
\hline $\begin{array}{l}\text { Zubair S.S. and } \\
\text { Ali Khan M. }\end{array}$ & 2019 & $\begin{array}{l}\text { - This study explored sustainable and environmentally friendly practices of human } \\
\text { resources management and recommended the same to adopt to the HRM department } \\
\text { of the organization in the flavoured of Green HRM. }\end{array}$ \\
\hline $\begin{array}{l}\text { Opatha, H.H.D.N.P. and } \\
\text { Hewapathirana, R.A. }\end{array}$ & 2019 & $\begin{array}{l}\text { - This research paper is a theoretical one and it explores the existing rich definitions } \\
\text { of GHRM from the literature which is available to the researchers. Further, the paper } \\
\text { presents a comprehensive definition of GHRM and its characteristics. }\end{array}$ \\
\hline $\begin{array}{l}\text { Mohammad, N., Bibi, Z., } \\
\text { Karim, J. and Durrani, } \\
\text { D, }\end{array}$ & 2020 & $\begin{array}{l}\text { - This paper focuses on researching the mediating effect of green passion to the } \\
\text { relationship of green human resource management (GHRM) and organizational } \\
\text { citizenship behaviour for the environment (OCBE). }\end{array}$ \\
\hline $\begin{array}{l}\text { Opatha, H.H.D.P. Jayani } \\
\text { and } \\
\text { Kottawatta, H. }\end{array}$ & 2020 & $\begin{array}{l}\text { - This study is an empirical one done in a Sri Lankan tiles manufacturing company. } \\
\text { It investigates the impact of green attitude on the green work behaviour of } \\
\text { employees. The found impact is positive and significant. }\end{array}$ \\
\hline $\begin{array}{l}\text { Geetha, U. and } \\
\text { Sammanasu, J.M. }\end{array}$ & 2020 & $\begin{array}{l}\text { - This research paper has been carried out by reviewing the recent literature on } \\
\text { Green HRM and as well its conceptual framework mainly focuses on Green HRM. }\end{array}$ \\
\hline
\end{tabular}

Source: Developed by Authors

According to the table, there were 68 research studies with regard to GHRM which were referred by the researchers of this research paper. Some studies were conceptual while others were empirical. Aspects empirically studied were basically regarding GHRM functions, GHRM practices in different industries in different countries, and influences and impacts of GHRM on organizational environment performance, organizational or firm performance, and corporate sustainability. Aspects conceptually studied were with regard to overviews of GHRM, defining green and GHRM, green attitudes, green behaviours, and green results.

\section{Some Research Gaps in Green HRM}

There are few research studies which had focus "on environmental behaviours at the individual employee level within the organization" (Daily et al., 2009, p.245). Many gaps exist in GHRM and they are to be filled theoretically and empirically as well (Jackson et al., 2011). "Indeed, there are many gaps to be filled in respect of GHRM, and theoretical and empirical studies are needed to enhance the body of knowledge of GHRM" (Opatha \& Arulrajah, 2014, p.109). It is vital and interesting to note that Opatha and Arulrajah (2014) discuss four "green human resource requirements, i.e. green competencies, green attitude, green behaviour, and green results"(p.105), which were identified as four concepts related to GHRM in a previous section. These concepts need to be empirically investigated and it seems that such empirical studies that investigate those concepts in one research design of GHRM area do not exist in the local context and more likely in the international context as well. Theoretically, there are arguments available in the existent literature (Opatha, 2013; Opatha \& Arulrajah, 2014; Opatha, 2019) with regard to the relationships which exist among "green attitude, green behaviour (green organizational citizenship behaviour, green interpersonal citizenship behaviour, and green official behaviour), and green results (green innovations and green outcomes)" (p.17, p.105, p.62). Green attitude is considered as green input and green behaviour and green results are the green performance of the job. Green attitude leads to or results in green behaviour and green results. Use of the theory of the ABC Model which consists of three components of an attitude, i.e. cognitive, affective, and behavioural, developed by Rosenberg, Hovland, McGuire, Abelson, and Brehm (1960) (as in Nelson and Quick, 1997) supports the composition of the green attitude. It is possible to develop a serious right attitude within an employee, who then believes in greening, feels positively and interestingly greening, and will have a serious behavioural intention to deal with greening. Green HRM consists of green functions such as green recruitment, green selection, green induction, green training, green performance evaluation, and green reward management, and these functions will jointly have a significant positive influence or impact on developing green attitude within the employee in the organization.

For the purpose of developing a strong theoretical foundation for our study, it is possible to utilize another useful general theory called MARS Model of Individual Behaviour developed by McShane, Glinow, and Sharma (2008) in which M stands for motivation, A stands for Ability, R stands for Role perceptions, and S stands for situational factors. According to the theory, these four factors lead to behaviour and results. Green orientation of HRM, particularly green selection, green training, green performance evaluation, and green rewards management are situational factors. The green attitude of the employee can be perceived as motivation. The employee can be oriented to perceive green citizenship behaviour, green interpersonal citizenship behaviour, and green official behaviour which are three components of green behaviour as critical roles to be played by him or her. 
Consequently, green behaviour and green results tend to occur.

In this context, another useful classic theory is the General System theory developed originally by Bertalanffy (1950) that explains how something can be materialized through taking inputs, processing, and giving outputs. This theory provides strong support to the position that the green orientation of HRM and green attitude as inputs lead to green behaviour which is processing and it leads to green results. As stated by Wright and Snell (1991) the general system theory discusses inputs, processes, and outputs. We intend to consider green orientation of HRM and green attitude as the inputs, green behaviour as the process, and green results as the output.

An employee who may be a manager or a non-manager in an organization is indeed a person. A person possesses what is called Personal Character (PC). According to Opatha and Teong (2014), personal character is a person's moral attributes. Further, Opatha (2010) explained "that the nature of a character, that has virtues to the utmost level and has no existence of vices, can be called the highest level of good personal character, and generally good habits are known as virtues and bad habits are known as vices". We believe that personal character has a significant moderating effect on the relationship between the green orientation of HRM and green attitude. Chaudhary (2018) emphasized that "individuals' attitudes and behaviors toward the organization are likely to be determined by their personal stance, values, and orientations" (p.306).

Thus, as far as our constructed context of GHRM for researching is considered, we identify the following research gaps:

Gap 1: There are no theoretical arguments and empirical evidence on the moderating effect of personal character on the relationship between green orientation of HRM and green attitude of the employee. It reveals that the moderating effect of the personal character of the employee on green orientation of HRM - green attitude linkage has neither been theoretically argued nor been empirically tested in the Sri Lankan context, perhaps in the international context.

Gap 2: There is no specific empirical evidence in the past research on the relationships which exist between green attitude and green personal behaviour, green organizational citizenship behaviour, green interpersonal citizenship behaviour, and green official behaviour. It has not been empirically tested in a study that green attitude as an independent variable is significantly related to green personal behaviour, green organizational citizenship behaviour, green interpersonal citizenship behaviour, and green official behaviour which are taken as dependent variables.

Gap 3:The review of seminal papers and key meta-reviews revealed that (Table 2) previous researchers have not focused on mediating effects of green attitude on the relationships between green orientation of HRM and the four specific types of green behaviour, i.e. green personal behaviour, green organizational citizenship behaviour, green interpersonal citizenship behavior, and green official behaviour. No theoretical arguments exist with regard to the moderating effects of green attitude on green orientation of HRM - the four specific types of green behaviour linkage. Furthermore, no empirical evidence is available in the existent literature with regard to that green attitude mediates the relationships between green orientation of HRM and the four specific types of green behaviour, i.e. green personal behaviour, green organizational citizenship behaviour, green interpersonal citizenship behavior, and green official behaviour.

Gap 4: The past empirical studies do not focus on finding the influence of green personal behaviour on perceived green results which include green innovations and green outputs. It is interesting to know whether green personal behaviour significantly influences on perceived green results within the organization.

Gap 5: There is no theoretical argument as well as empirical evidence in the existent literature with regard to the relationship between green organizational citizenship behaviour and perceived green results. The linkage between green organizational citizenship behaviour and perceived green results has not yet been theoretically argued and empirically tested locally and perhaps internationally as well.

Gap 6: Both theoretical argument and empirical evidence do not exist in the past research done locally and perhaps internationally too with regard to the relationship between green interpersonal citizenship behaviour and perceived green results. A research need arises to argue and to test too whether these two variables are related significantly or not.

Gap 7: Green official behavior has not been considered as an independent variable that influences significantly on perceived green results in the organization in the previous studies. A research need arises to develop arguments and empirical evidence to establish green official behaviour - perceived green results linkage.

Gap 8: No local and perhaps international studies are available arguing and testing empirically with regard to the combined effect of green personal behaviour, green organizational citizenship behaviour, green interpersonal 
citizenship behaviour, and green official behaviour on perceived green results. It is interesting to uncover that these four variables would jointly explain a significant percentage of variability of perceived green results.

\section{Future Implications}

Eight research gaps were identified and mentioned specifically in the above section of this article. Two gaps numbered 2 and 4 can be considered as empirical gaps while the other six gaps numbered 1, 3, 5, 6, 7, and 8 are theoretical as well as empirical gaps. Our attempt of identification of these research gaps implies that future studies need to be carried out to fill the gaps. Indeed these studies need to be systematic and scientific so as to contribute to the existing body of knowledge of GHRM in a way that is acceptable to the academic community. The adoption of systematic and scientific research methods, the particularly hypothetico-deductive approach requires measuring the variables in a way that is valid as well as reliable. The existing literature does not provide valid and reliable instruments which can be adopted or adapted for the purpose of measuring variables such as green attitude, green personal behaviour, green official behavior, and perceived green results considered in this research paper. This is also a gap that can be identified as a methodological gap, which necessitates the development of valid and reliable instruments for the variables. All the variables under the gaps identified in this paper include green orientation of HRM, personal character, green attitude, green personal behaviour, green organizational citizenship behaviour, green interpersonal citizenship behaviour, green official behaviour, and perceived green results. When these variables are positioned in a research framework, a network of relationships gets created and it is shown in figure 1 .

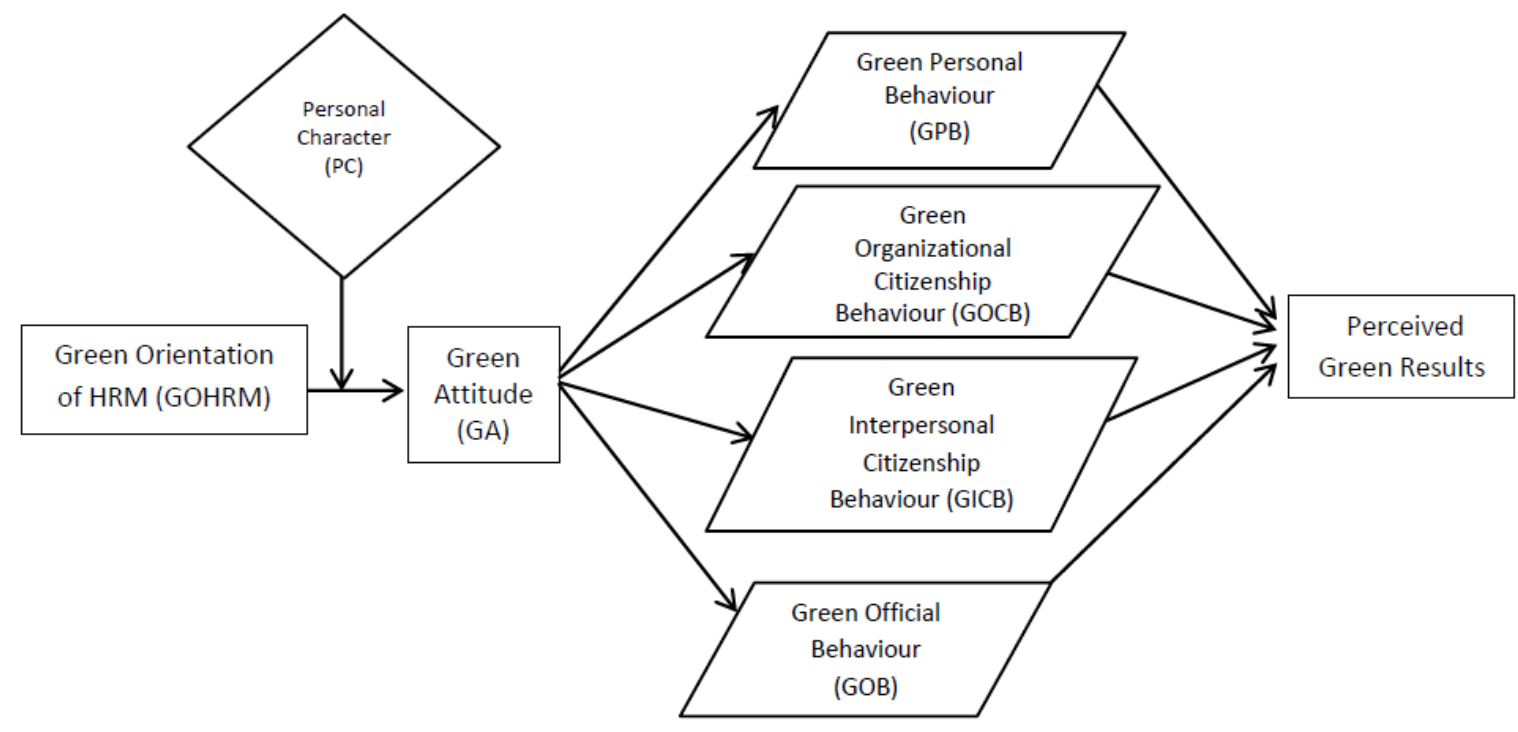

Figure 1. Nomological Network

Source: Authors' Construction

\section{Conclusion}

GHRM has emerged as a critical branch of HRM and it has a great potential to serve for environmental sustainability which is a must for sustaining the people and society and organizations. It was attempted to present a brief introduction to Green HRM and identify related concepts, to explore and specify the key studies on Green HRM, to present certain research gaps in Green HRM, and to discuss future implications. Mainly the attempt by adopting a desk research strategy was to identify certain research gaps in GHRM and it was possible to identify nine research gaps. Six gaps are both theoretical and empirical and two gaps are only empirical. The gap with regard to the instrumentation of the four variables or constructs is methodological. A research framework was developed by positioning all the variables considered (i.e. green orientation of HRM, personal character, green attitude, green personal behaviour, green organizational citizenship behaviour, green interpersonal citizenship behaviour, green official behaviour, and perceived green results) in a network of relationships. Future research studies that are systematic and scientific will need to be carried out to fill the identified research gaps in GHRM. 


\section{References}

Aggarwal, S., \& Sharma, B. (2015). Green HRM: need of the hour. International Journal of Management and Social Science Research Review, 1(8), 63-70.

Arqawi, S., Zaid, A. A., Ayham, A. M., Al hila, A. J., Al Shobaki, M. J., \& Abu-Naser, S. S. (2019). Green human resource management practices among Palestinian manufacturing firms - An exploratory study. Journal of Resources Development and Management, 52, 62-69. https://doi.org/10.7176/JRDM

Arulrajah, A. A., \& Opatha, H. H. D. N. P. (2016). Analytical and theoretical perspectives on green human resource management: A simplified underpinning. International Business Research, 9(12), 153-164. https://doi.org/10.5539/ibr.v9n12p153

Arulrajah, A. A., Opatha, H. H. D. N. P., \& Nawaratne, N. N. J. (2015). Green human resource management practices: A review. Sri Lankan Journal of Human Resource Management, 5(1), 1-16. https://doi.org/10.4038/sljhrm.v5i1.5624

Arulrajah, A. A., Opatha, H. H. D. N. P., \& Nawaratne, N. N. J. (2016). Employee green performance of job: A systematic attempt towards measurement. Sri Lankan Journal of Human Resource Management, 6(1), 37-62. https://doi.org/10.4038/sljhrm.v6i1.5631

Aykan, E. (2017). Gaining a competitive advantage through green human resource management. In O. L. Emeagwali (Eds.), Corporate governance and strategic decision making, London, United Kingdom,IntechOpen. https://doi.org/10.5772/intechopen.69703

Azmi, F. R., Musa, H., Shahbodin, F., Hazmilah, H., \& Fam, S. (2017). Implementation of green human resource management in Malaysia. Paper presented at Mechanical Engineering Research Day 2017, 257-258.

Banerjee, S., \& Dutta, A. B. (2017). Green HRM: A brief review. Rainbow Multidisciplinary Pre Reviewed Annual Journal, 3(2017), 1-5.

Bangwal, D., \& Tiwari, P. (2015). Green HRM - A way to greening the environment. Journal of Business and Management (IOSR-JBM), 17(12/1), 45-53. https://doi.org/10.1504/IJEWE.2017.087808

Bangwal, D., Tiwari, P., \& Chamola, P. (2017). Green HRM, work-life and environment Performance. Int. J. Environment, Workplace, and Employment, 4(3), 244-268. https://doi.org/10.1504/IJEWE.2017.087808

Bertalanffy, L.V. (1950). An outline of general system theory. The British Journal for the Philosophy of Science, I(2), 134-165. https://doi.org/10.1093/bjps/I.2.134

Bissing-Olson, M. J., Iyer, A., Fielding, K. S., \& Zacher, H. (2013). Relationships between daily affect and pro-environmental behavior at work: The moderating role of pro-environmental attitude. Journal of Organizational Behavior, 34(2), 156-175. https://doi.org/10.1002/job.1788

Bohlmann, C., Jeroen, V. D. B., \& Zacher, H. (in press). The relative importance of employee green behavior for overall job performance ratings: A policy-capturing study. In Richard Welford (Eds.), Corporate Social Responsibility and Environmental Management, Sasin School of Management, Bangkok. Retrieved from http://onlinelibrary.wiley.com/journal/10.1002/(ISSN)1535-3966

Bombiak, E., \& Marciniuk-Kluska, A. (2018). Green human resource management as a tool for the sustainable development of enterprises: Polish young company experience. Sustainability, 10(1739), 1-22. https://doi.org/10.3390/su10061739

Chaudhary, R. (2018). Can green human resource management attract young talent? An empirical analysis. Evidence-based HRM: A Global Forum for Empirical Scholarship, 6(3), 305-319. https://doi.org/10.1108/EBHRM-11-2017-0058

Collins Birmingham University International Language Database (Co build) English Language Dictionary (1987). London: Collins.

Coskun, A. (2017). Understanding green attitudes. In Quoquab, F., Thurasamy, R., and Jihad Mohammad, J. (Eds.), Driving green consumerism through strategic sustainability marketing. Hershey PA, USA. https://doi.org/10.4018/978-1-5225-2912-5.ch004

Daily, B. F., Bishop, J. W., \& Govindarajulu, N. (2009). Conceptual model for organizational citizenship behavior directed toward the environment. Business \& Society, 48, 243-256.

https://doi.org/10.1177/0007650308315439

Dangmei, J. (2015). Green HRM: can it preserve the habitations of tribal people? Jaanjatiya Shodh Aug 2015- 
Jan 2016, 85-88.

Das, S. C., \& Singh, R. K. (2016).Green HRM and organizational sustainability: An empirical review. kegees Journal of Social Science, 8(1), 227-236.

Dhawan, S. (2019). Green HR practices and environment sustainability: A study of Indian companies. Journal of Emerging Technologies and Innovative Research (JETIR), 6(4), 501-508. Retrieved from www.jetir.org

Dumont, J. (2015). Green human resource management and employee workplace outcomes (Doctoral dissertation). University of South Australia. https://doi.org/10.5465/ambpp.2015.11427abstract

Dumont, J., Jie, S., \& Xin, D. (2017). Effects of green HRM practices on employee workplace green behavior : The role of psychological green climate and employee green values. Human Resource Management $(2016$ Wiley Periodicals, Inc. Published online in Wiley Online Library (wileyonlinelibrary.com), 56(4), 613-627. https://doi.org/10.1002/hrm.21792

Dutta, S. (2012). Greening people: A strategic dimension. International Journal of Business Economics \& Management Research, 2(2), 143-148. Retrieved from http://zenithresearch.org.in/

Eryuruk, S. H. (2012). Greening of the textile and clothing industry. Fibres \& Textiles in Eastern Europe 2012, 20(6A/95), 22-27.

Geetha, U., \& Sammanasu, J. M. (2020). Green HRM - A conceptual framework. Journal of Xi'an University of Architecture \& Technology, 7(5), 1204-1212.

Gholami, H., Rezaei, G., Mat Saman, M. Z., Sharif, S., \& Zakuan, N. (2016). State-of-the-art green HRM system: sustainability in the sports center in Malaysia using a multi-method approach and opportunities for future research. Journal of Cleaner Production, 124, 142-163. https://doi.org/10.1016/j.jclepro.2016.02.105

Guerci, M., \& Carollo, L. (2015). A paradox view on green human resource management: insights from the Italian context. The International Journal of Human Resource Management, 27(2), 212-238. https://doi.org/10.1080/09585192.2015.1033641

Halawi, A., \& Zaraket, W. (2018). Impact of green human resource management on employee behaviour. Journal of Applied Business Research, 18-34. https://doi.org/10.1108/00251740910978322

Jabbar, M. H., \& Abid, M. (2015). A study of green HR practices and its impact on environmental performance. MAGNT Research Report, 3(8), 142-154.

Jabbour, C. J. C. (2011). How green are HRM practices, organizational culture, learning and teamwork? A Brazilian study. Industrial and Commercial Training, 43(2), 98-105. https://doi.org/10.1108/00197851111108926

Jabbour, C. J. C., Santos, F. C. A., \& Nagano, M. S. (2010). Contribution of HRM throughout the stages of environmental management: methodological triangulation applied to companies in Brazil. The International Journal of Human Resource Management, 21(7-9), 1049-1089. https://doi.org/10.1080/09585191003783512

Jackson, S. E., Renwick, D. W. S., Jabbour, C. J. C., \& Muller-Camen, M. (2011).State-of-the-art and future directions for green human resource management. Zeitschriftfür Personal forschung, 25(n.2), 99-116. https://doi.org/10.1177/239700221102500203

Javed, F., \& Cheema, S. (2017). An empirical investigation on the impacts of the adoption of green HRM in the agricultural industry. Journal of Internet Banking and Commerce, 22(S8), 01-14. Retrieved from http://www.icommercecentral.com

Kumar Kar, A., \& Praharaj, L. (2017).Green HRM: An innovative practice for organizational sustainability, Iranian Journal of Scientific Research (IIJSR), 1(1), 46-56.

Lee, Ki-hoon (2009). Why and how to adopt green management into business organizations? The case study of Korean SMEs in manufacturing industry. Management Decision, 47(7), 1101-1121. https://doi.org/10.1108/00251740910978322

Macduffie, J. P. (1995). Human resource bundles and manufacturing performance: organizational logic and flexible production systems in the world auto industry. Industrial and Labor Relations Review, 48(2), 197-221. https://doi.org/10.1177/001979399504800201

Manaktola, K., \& Jauhari, V. (2007). Exploring consumer attitude and behavior towards green practices in the lodging industry in India. International Journal of Contemporary Hospitality Management, 19(5), 364-377. 
https://doi.org/10.1108/09596110710757534

McShane, S. L., Glinow, M. A. V., \& Sharma, R. R. (2008). Organizational Behaviour, New York: McGraw-Hill (Indian Edition).

Mehta, K., \& Chugan, P. K. (2015). Green HRM in pursuit of environmentally sustainable business. Universal Journal of Industrial and Business Management, 3(3), 74-81. https://doi.org/10.13189/ujibm.2015.030302

Mesmer-Magnus, J., Viswesvaran, C., \& Wiernik, B. M. (2012). The role of commitment in bridging the gap between organizational sustainability and environmental sustainability. In S. E. Jackson, D. S. Ones, \& S. Dilchert (Eds.), The SIOP professional practice series. Managing human resources for environmental sustainability, Jossey-Bass/Wiley, 86-104. https://doi.org/10.1002/joe.21506

Mohammad, N., Bibi, Z., Karim, J., \& Durrani, D. (2020). Green human resource management practices and organizational citizenship behaviour for environment: The Interactive Effects of Green Passion. International Transaction Journal of Engineering, Management, \& Applied Sciences \& Technologies, 11(6), $1-10$.

Nejati, M., \& Ahmad, N. H. (2015). Job Seekers' Perception of Green HRM, Conference on Green Human Resource Management (CGHRM) 2015, 92-101. Graduate School of Business, Universiti Sains Malaysia, Penang.

Nelson, D. L., \& Quick, J. C. (1997). Organizational Behavior: Foundations, Realities, and Challenges. New York: West Publishing Company.

Obaid, T. F., \& Alia, R. B. (2015). The impact of green recruitment, green training, and green learning on the firm performance: Conceptual paper. International Journal of Applied Research, 1(12), 951-953. Retrieved from www.allresearchjournal.com

Opatha, H. H. D. N. P. (2013). Green human resource management: A simplified introduction, HR Dialogue, Department of HRM, Faculty of Management Studies and Commerce, University of Sri Jayewardenepura, 11-21. https://doi.org/10.5539/ibr.v7n8p101

Opatha, H. H. D. N. P. (2016). Towards a sustainable future: Reflections. Sri Lankan Journal of Human Resource Management, 6(1), 2-12. https://doi.org/10.4038/sljhrm.v6i1.5629

Opatha, H. H. D. N. P. (2019). Sustainable human resource management- Expanding horizons of HRM. Colombo, University of Sri Jayewardenepura.

Opatha, H. H. D. N. P., \& Anton Arulrajah, A. (2014). Green human resource management: Simplified general reflections. International Business Research, 7(8), 101-112. https://doi.org/10.5539/ibr.v7n8p101

Opatha, H. H. D. N. P., \& Hewapathirana, R. A. (2019). Defining green and green human resource management: A conceptual study. International Journal of Arts and Commerce, 8(5), 1-10.

Opatha, H. H. D. P. J., \& Kottawatta, H. (2020). Impact of green attitude on green work behavior: An empirical study of employees in a Sri Lankan tiles manufacturing company. Asian. Jour. Social. Scie. Mgmt. Tech., 2(4), 01-07.

Opatha, H. H. D. N. P. (2010). Personal quality, Colombo, Sri Lanka.

Opatha, H. H. D. N. P., \& Teong, L. K. (2014). Enhancing your PQ. Sintok, Universiti Utara Malaysia, UUM Press.

Pallavi, E. V. P. A. S., \& Bhanu, M. V. V. (2016). Green HRM: A way for corporate sustainability. International Journal of Human Resource Management and Research (IJHRMR), 6(2), 13-20.

Pavitra, M. (2017). Green human resource management: A framework for sustainable organizational development in an emerging economy. International Journal of Organizational Analysis, 25(5), 762-788. https://doi.org/10.1108/IJOA-11-2016-1079

Pawar, A. (2016). Review on implications of green human resource management in business. International Journal in Management and Social Science, 04(4), 284-291. Retrieved fromhttp://www.ijmr.net.in

Pham, N. T., Tuckova, Z., \& Phan, Q. P. T. (2019). Greening human resource management and employee commitment towards the environment: An interaction model. Journal of Business Economics and Management, 20(3), 446-465. https://doi.org/10.3846/jbem.2019.9659

Purba, R. (2004). Greening production: a South-East Asian experience. International Journal of Operations \& Production Management, 24(3), 289-320. https://doi.org/10.1108/01443570410519042 
Ragas, S. F. P., Tantay, F. M. A, Co Chua, L. J., \& Concha Sunio, C. M. (2017). Green lifestyle moderates GHRM's impact on job performance. International Journal of Productivity and Performance Management, 66(7), 857-872. https:// doi.org/10.1108/IJPPM-04-2016-0076

Ren, S., Tang, G. Y., \& Jackson, S. E. (2017). Green human resource management research in emergence: A review and future directions. Asia Pacific Journal of Management, 32(1), Springer Science+Business Media, LLC 2017. https://doi.org/10.1007/s10490-017-9532-1

Renwick, D. W. S., Jabbour, C. J. C., Muller-Camen, M., Redman, T., \& Wilkinson, A. (2015). Contemporary developments in green (environmental), HRM scholarship. The International Journal of Human Resource Management, 1-15. https://doi.org/10.1080/09585192.2015.1105844

Renwick, D. W. S., Redman, T., \& Maguire, S. (2008).Green HRM: A review, process model, and research agenda. Discussion Paper Series No 2008.01, University of Sheffield Management School, 9 Mappin Street, Sheffield, 1-41.

Renwick, D. W. S., Redman, T., \& Maguire, S. (2012). Green human resource management: A review and research agenda. International Journal of Management Reviews, (C) 2012 British Academy of Management and Blackwell Publishing Ltd., 1-14. https://doi.org/10.1111/j.1468-2370.2011.00328.x

Saeed, B. B., Afsar, B., Hafeez, S., Khan, I., Tahir, M., \& Muhammad, A. A. (2018). Promoting employee's pro-environmental behavior through green human resource management practices. wileyonlinelibrary.com/journal/csr, Corp Soc Resp Env Ma, 2019, 26, 424-438. https://doi.org/10.1002/csr.1694

Shah, M. (2019). Green human resource management: Development of a valid measurement scale. Research Article Bus Strat Env., 1-15. Retrieved from wileyonlinelibrary.com/journal/bse @ 2019 John Wiley \& Sons, Ltd and ERP Environment. https://doi.org/10.1037/t76860-000

Shahriari, B., \& Hassanpoor, A. (2019). Green human resource management in the East and West. Revista Gestão \& Tecnologia, 19(2), 27-57. https://doi.org/10.20397/2177-6652/2019.v19i2.1546

Shoeb, A. (2015). Green human resource management: policies and practices, management review article. Cogent Business \& Management, 1-13. https://doi.org/10.1080/23311975.2015.1030817

Siyambalapitiya, J., Xu, Z., \& Liu, X. B. (2018). Green human resource management: A proposed model in the context of Sri Lanka's tourism industry. Journal of Cleaner Production, 201, 542-555. https://doi.org/10.1016/j.jclepro.2018.07.305

Smith, E. E., \& Perks, S. (2010). A perceptual study of the impact of green practice implementation on the business functions, Southern African Business Review, 14, 1-29.

Suhaimi, S. (2011). Strategic green HRM: A proposed model that supports corporate environmental citizenship. International Conference on Sociality and Economics Development, IPEDR vol.10 @ (2011) IACSIT Press, Singapore, 79-83.

The Oxford Paperback Dictionary (1979). Oxford: Oxford University Press.

The Oxford Thesaurus of English (2000). Oxford: Oxford University Press.

Toprak, T., \& Anis, P. (2017). Textile industry's environmental effects and approaching cleaner production and sustainability, an overview. Journal of Textile Engineering \& Fashion Technology, 2(4), 429-442. https://doi.org/10.15406/jteft.2017.02.00066

Wayne, O., \& Nuttaneeya, A. T. (2016). The moderating effect of 'Green' HRM on the association between proactive environmental management and financial performance in small firms. The International Journal of Human Resource Management, 27(2), 239-261. https://doi.org/10.1080/09585192.2015.1063078

Wehrmeyer, W. (1996). Greening People: Human Resources and Environmental Management. Sheffield: Greenleaf Publishing.

Wright, P. M., \& Snell, S. A. (1991). Toward an integrative view of strategic human resource management. Human Resource Management Review, 1(3), 203-225. https://doi.org/10.1016/1053-4822(91)90015-5

Yong, J. Y., Yusliza, M. Y., \& Fawehinmi, O. O. (2019). Green human resource management: A systematic literature review from 2007 to 2019. Benchmarking: An International Journal. https://doi.org/10.1108/BIJ-12-2018-0438

Yua, W., Chavezb, R., Fengc, M., Wongd, C. Y., \& Fynese, B. (2019). Green human resource management and 
environmental cooperation: An ability-motivation-opportunity and contingency perspective. International Journal of Production Economics, 224-235. https://doi.org/10.1016/j.ijpe.2019.06.013

Yusliza, M. Y., Othman, N. Z., \& Jabbour, C. J. J. (2017). Deciphering the implementation of green human resource management in an emerging economy. Journal of Management Development, 36(10), 1230-1246. https://doi.org/10.1108/JMD-01-2017-0027

Yusoff, Y. M., Othman, N. Z., Fernando, Y., \& Amran, A. (2015). Conceptualization of green human resource management: An exploratory study from Malaysian-based multinational companies. International Journal of Business Management and Economic Research (IJBMER), 6(3), 158-166.

Yusuph, M. L. (2018). Green human resource management and environmental sustainability in Tanzania: A review and research agenda. International Journal of Academic Multidisciplinary Research (IJAMR), 2(12), 60-68. Retrieved from www.ijeais.org/ijamr

Zaid, A. A., Bon, A. T., \& Jaaron, A. A. M. (2018). Green human resource management bundle practices and manufacturing organizations for performance optimization: A conceptual model. International Journal of Engineering \& Technology, 7(3.20), 87-91. https://doi.org/10.14419/ijet.v7i3.20.18986

Zubair, S. S., \& Ali Khan, M. (2019). Sustainable development: The role of green HRM. International Journal of Research in Human Resource Management, 1(2), 1-6.

\section{Copyrights}

Copyright for this article is retained by the author(s), with first publication rights granted to the journal.

This is an open-access article distributed under the terms and conditions of the Creative Commons Attribution license (http://creativecommons.org/licenses/by/4.0/). 